\title{
Interaction Effect of Self-Concept and Study Habits on Academic Achievement in Mathematics
}

\author{
Parvinder Singh \\ P. G. Department of Mathematics, S. G. G. S. Khalsa College, Mahilpur. (Hoshiarpur), Punjab. (India)
}

\begin{abstract}
Self-concept is our perception or image of our abilities and our uniqueness. Similarly study habits of a student vary from person to person. Academic performance is a complex student behavior and underlies several abilities, e.g., memory, previous knowledge or aptitude as well as psychological factors such as motivation, interests, temperaments or emotions, and way of the study such as time management, note taking, use of library etc. to name a few. In this study attempt has been made to find a relationship between selfconcept and study habits with academic achievement in mathematics and also to find the interactional effect of self-concept and study habits on academic achievement in mathematics.
\end{abstract}

Keywords: Self-concept, Study Habits, Academic Achievements

\section{Introduction}

It is said that mathematics is the gate and key of all sciences. According to the famous philosopher Kant (1785) stated that "A science is exact only if so far as it employs mathematics. So all scientific education which does not commence with mathematics is said to be defective at its foundation. Neglect of Mathematics works injury to all subjects."

In twentieth century mathematics become a major profession. Every year thousands of students pass out from colleges and universities with various levels of degrees awarded to them. Numerous jobs are available both in teaching and industry. In most areas of the study of mathematics, the explosion of knowledge in scientific age has led to specialization. By the end of the century, hundreds of specialized areas in mathematics were explored. Every pupil has to learn mathematics from his first day to school and to the end of his study period. Therefore there is a great need to observe the teaching and learning process in mathematics so that this important subject is so presented to the students that they have great interest in the subject and attain more and more knowledge of the subject.

\subsection{Nature of Mathematics}

Mathematics is the science of logical reasoning where results are developed through the process of logic, analysis and evaluation. By far most significant development in mathematics was giving it firm logical foundations. This took place in ancient Greece in the centuries proceeding Euclid. Logical foundations prefered mathematics more than just certainly the tool to investigate the unknown. As a science of abstract objects, mathematics relies on logic rather than on observation as its standard of truth. It employs observation, simulation and even experimentation as means of discovering the truth. The special role of mathematics in education is a consequence of its universal applicability.

According to Haris Kline, Mathematics is a spirit of nationality. It is that challenge which stimulates invigorates and drives human mind to exercise them to the fullest.

\subsection{Mathematics as an Academic Discipline}

Universalization of school education has important implications for mathematics curriculum. Mathematics up to high school level is a compulsory discipline and access to quality mathematics education is every child's right. In the words of David Wheeler (1965) "It is more useful to know how to mathematise than to know a lot of mathematics." More important is what mathematics offers is a way of doing things: to be able to solve mathematical problems and more generally to have the right attitude for problem solving and be able to handle all kinds of problems in a systematic way.

In 1937 when Gandhiji propounded the idea of basic education, Zakir Hussain committee was appointed to elaborate on this idea. The committee had recommended that: "Knowledge of mathematics is essential part of any curriculum. Every child is expected to work out the ordinary calculations requisite in the course of his craft work or his personal and community concerns and activities." The Secondary Education Commission (1952) as very much emphasized the need for mathematics education in schools. The National Policy on Education (1986) elaborated that "Mathematics should be visualized as the vehicle to train a child to think, reason, analyze and articulate logically. Apart from being a specific subject it should be treated as a concomitant to any subject involving analysis, and reasoning."

\subsection{Self-concept}

Not to be confused with self awareness, self consciousness, self Image or self perceptions. Self-concept (also called selfconstruction, self identity or self perspective) is a multidimensional construct that refers to an individual ${ }^{e e} s$ perception of ,Selfe in relation to any number of characteristics such as academics and non academics. Selfconcept is an internal model which comprises self assessment. To gain a better understanding of our selfconcept it is important that we examine our personality. An analysis of our thoughts and feelings about ourselves and the world around us can assist us in this process. 


\section{International Journal of Science and Research (IJSR) \\ ISSN (Online): 2319-7064}

Index Copernicus Value (2013): 6.14 | Impact Factor (2014): 5.611

According to the ,Dictionary of Education ${ }^{\text {ee }}$ by Taneja (1989) "self concept refers to the picture or image a person has of himself.

"Self-concept is the product of reflectivity; it is the concept of the individual of himself as a physical, social and moral and existing being. The self-concept is sum total of the individual 's thought and feelings about him or herself as an object "John (2000).

\subsection{Self-concept and Academic Achievement}

Self-concept is frequently positively correlated with academic performance, but it appears to be a consequence rather than a cause of high achievement. This suggests that increasing studentse academic skills is a more effective means to boost their self-concept than vice versa.

Most of the researches showed relentless support towards the belief that there is a significant relationship between academic self-concept and academic achievement in secondary and post-secondary school students (Cokley, 2007; Gordon, 1997; Yara, 2010). Recent study by Yara (2010) on student's self-concept and mathematics achievement in some secondary schools in South-Western Nigeria revealed that students with good self-concept perform well in mathematics. Cokley (2007) found that the grade point average was the best predictor of academic selfconcept for students attending predominantly white colleges and universities.

\subsection{Study Habits}

It is rightly said that character is the bundle of habits. This reveals the importance of habits in character. Education helps the learner in development of self-concepts and the attainment of knowledge by ways of good study habits. Every student have different kinds of study habits, some study regularly, some study when examinations approaches nearly. Some study while listening music while some study in complete silence and calm. No matter how dull or bright a student is he can, make most of his ability only if his study habits are superior and effective and he devote plenty of his time towards his studies.

Study habits are an individual ability. Some children like to read alone, some in a group, some read aloud and some silently; there is no strict yardstick to measure the type of study habits. It may be innate or acquired. The child can formulate its own study habits by itself. According to Webster's new world dictionary (fifth edition, 2014) "study is the act or process of applying the mind in order to acquire knowledge, as is reading, investigation etc."

Azikiwe (1998) described the study habits as "The adopted way or manner a student plans his private readings, after class-room learning so as to attain mastery of the subject" According to her, "Good study habits are good assets to learners because they assist students to attain mastery in areas of specialization and consequent excellent performance, while opposite constitute constraints to learning and achievement leading to failure." Good (1993) define study habits as "The student"s way of study, whether systematic, efficient or inefficient etc".

\subsection{Study habits and Academic Achievement}

Many students are unsuccessful in their examinations not because they are short of knowledge or ability, but because they do not have adequate study habits and study skills (Menzal, 1982). Good students are not born but are made by regular and deliberate practice of fine study habits for which there is no alternative. Thus in order to improve studentes academic achievement in different aspects of education it is essential to improve their good study habits. According to (Kizlik 2001) development of good study habits in children depends upon the collective efforts of parents and teachers. Study habits are the pattern of behaviour adopted by students in the pursuit of their studies which serves as the vehicle of learning.

\section{Review of Related Literature}

Fin and Ishak (2014) undertaken a study to confirm the role of academic self-concept as intermediary for non academic self-concept and academic achievement. The conclusion of the study suggested the need to generate consciousness among educators, parents and people for's the importance of academic self-concept and non-academic self-concept for facilitating student ${ }^{\text {ee }}$ s academic achievement.

Singh and Sarka (2015) undertook a study to investigate the relationship, at primary school level, between a child's beliefs about their ability to perform academic tasks i.e. ,academic self-concept ${ }^{e e}$ and achievement in mathematics. By means of Young Lives quantitative and qualitative data from the state of Andhra Pradesh, India, the study shows there was a significant and positive correlation between the academic self-concept and the growth in mathematics of students in primary schools.

Viji (2013) conducted a study on study habits, attitude towards mathematics and achievement in mathematics of secondary schools of Kanchipuram district. By using study habit inventory developed by B.V Patel (1976) and modified Fennema-Sherman mathematics attitude scale. Study reveals that there was no significant difference in study habits of a student based on gender \& there was a significant difference between study habits and medium of instruction.

Onoshakpokaiyee (2015) examined the relationship between study habits of students and their achievement in mathematics. The results of the students in mathematics were also collected from their various schools to gather data for their achievement in mathematics. Regression and ANOVA were used to analyze the data. Study revealed that there was a significant relationship between study habits and achievement in mathematics. There was a significant difference in achievement in mathematics and between good study habits and poor study habits.

\subsection{Objectives of the study}

The present study was undertaken by keeping in view the following objectives: 


\section{International Journal of Science and Research (IJSR) \\ ISSN (Online): 2319-7064 \\ Index Copernicus Value (2013): 6.14 | Impact Factor (2014): 5.611}

1)To study the relationship between academic achievement in mathematics and self- concept of the students.

2)To study the relationship between academic achievement in mathematics and study habits of the students.

3) To study the interactional effect of self-concept and study habits with academic achievement in mathematics.

\subsection{Hypotheses of the study}

From above mentioned objectives the following null hypotheses have been framed:

H1: There is no significant relationship between academic achievement in mathematics and self-concept of the students.

$\mathrm{H} 2$ : There is no significant relationship between academic achievement in mathematics and study habits of the students.

H3: There is no significant interactional effect of selfconcept and study habits of a student on academic achievement in mathematics.

\subsection{Tool used}

The following Research tools were used to collect data for the present study

1. Self-Concept Scale (R.K. Saraswat, 1992).

2. Study-Habit Inventory (Mukhopadhaya and Sansanwal, 2005).

\subsection{Sample}

In the present study researcher had selected a sample of 600 students of class XI and XII from the Government and NonGovernment senior secondary Schools of Hoshiarpur, Jalandhar and Nawanshahar districts. From each of these districts namely Hoshiarpur, Jalandhar and Nawanshahar 200 students were selected for sample out of which 100 are boys and 100 are girls.

\section{Results and Discussion}

Table 1.1: ANOVA analysis of the academic achievement of the students categorized on basis of their self-concept

\begin{tabular}{|c|c|c|c|c|}
\hline Category & $N$ & Mean & SD & F Test \\
\hline Average self-concept & 27 & 69.22 & 14.05 & 1.97 \\
\hline $\begin{array}{c}\text { Above Average self- } \\
\text { concept }\end{array}$ & 477 & 74.45 & 14.351 & $\mathrm{p}=0.249$ \\
\hline High self-concept & 96 & 75.29 & 15.137 & $\mathbf{p}=\mathbf{0 . 2 4 9}$ \\
\hline Total & $\mathbf{6 0 0}$ & $\mathbf{7 4 . 3 5}$ & $\mathbf{1 4 . 4 8 7}$ & Significant \\
\hline
\end{tabular}

\subsection{Hypothesis H1}

Table 1.1 shows that mean academic achievement score in mathematics with average self-concept is 69.22 with standard deviation of 14.050 , with above average self-concept the mean score is 74.45 with standard deviation of 14.351 , with high self-concept score is 75.29 with standard deviation of 15.137, the null hypothesis assumed $\mathrm{H} 1$ is rejected as $\mathrm{F}$ value is 1.970 and $p$ value is 0.249 which is significant at .01 level of significance and shows that there is significant relationship among the different categories of the selfconcept of the students with their academic achievement scores in mathematics.

Table 1.2: ANOVA Analysis of Academic Achievement of the Students Categorized on Basis of Their Study Habit Scores

\begin{tabular}{|c|c|c|c|c|}
\hline Category & $\mathbf{N}$ & Mean & SD & F Test \\
\hline High study habits & 1 & 68.00 & & \multirow{6}{*}{ Significant } \\
\hline $\begin{array}{c}\text { Above Average study } \\
\text { habits }\end{array}$ & 1 & 83.00 & & \\
\hline Moderate study habits & 23 & 82.43 & 14.352 & \\
\hline $\begin{array}{c}\text { Below Average study } \\
\text { habits }\end{array}$ & 108 & 75.16 & 16.120 & \\
\hline Poor study habits & 219 & 53.03 & 14.669 & \\
\hline Very Poor study habits & 248 & 51.35 & 13.536 & \\
\hline Total & 600 & 74.33 & 14.534 & \\
\hline
\end{tabular}

\subsection{Hypothesis $\mathrm{H} 2$}

From the table 1.2 it was observed that the students having high study habits have 68.00 mean score on academic achievement in mathematics, with above average study habits mean score was 83.00 , with moderate study habits mean score was 82.43 with standard deviation of 14.352 , with below average study habits mean score was 75.16 with standard deviation of 16.120 , with poor study habits mean score was 53.03 with standard deviation of 14.669 and with very poor study habits mean score was 51.35 with standard deviation of 13.536. F value of the test was 1.975 and $p$ value was 0.281 which is significant thus the null hypothesis assumed H2 was rejected as there is significant relationship reported among the different study habits of the students with their academic achievement scores in mathematics.

Table 1.3: ANOVA Analysis (with interaction) of the effect of Self-Concept and Study Habits on Academic Achievement in Mathematics

\begin{tabular}{|c|c|c|c|c|c|}
\hline Source & $\begin{array}{c}\text { Type III Sum } \\
\text { of Squares }^{2}\end{array}$ & $\begin{array}{c}\text { Mean } \\
\text { Square }\end{array}$ & F & $\begin{array}{c}\text { P } \\
\text { value }\end{array}$ \\
\hline Corrected Model & $6982.226^{\mathrm{a}}$ & 12 & 581.852 & 2.858 & 0.001 \\
\hline Intercept & 167179.154 & 1 & 167179.154 & 821.173 & 0.000 \\
\hline Self-concept & 591.198 & 2 & 295.599 & 1.452 & 0.235 \\
\hline Study Habits & 2147.714 & 5 & 429.543 & 2.110 & 0.063 \\
\hline $\begin{array}{c}\text { Self-concept* } \\
\text { Study Habits }\end{array}$ & 4159.727 & 5 & 831.945 & 4.086 & 0.001 \\
\hline Error & 118486.867 & 582 & 203.586 & & \\
\hline Total & 3412613.000 & 595 & & & \\
\hline Corrected Total & 125469.092 & 594 & & & \\
\hline
\end{tabular}

\subsection{Hypothesis $\mathrm{H3}$}

Table 1.3 shows that the null hypothesis assumed H3 had been rejected as there is significant interactional effect ( $\mathrm{p}=$ $0.001<0.05$ ) of the self-concept and study habits been reveled for the academic achievement in mathematics of the students. Thus it is concluded that combined effect of the self-concept and study habits has strong association with

\section{Volume 4 Issue 11, November 2015}


academic achievement in mathematics of a student.

\section{Conclusions}

The study revealed that

- There is significant relationship among the different categories of the self-concept of the students with their academic achievement in mathematics.

- There is significant relationship among the different categories of the study habits of the students with their academic achievement in mathematics.

- There is significant relationship between academic achievement in mathematics and combined effect of self concept and study habits.

\section{References}

[1] Azikiwe, U. (1998). Study approaches of university students, WCCI region II forum. (2), logos ,104-106.

[2] Cokley, K.(2007). An investigation of self concept and its relation to academic achievement in African American college students. Journal of Black Psychology, 26,(2), 148-164.

[3] Fin, L.S.,\& Ishak, Z.(1014). Non academic self-concept and academic achievement: The indirect effect mediated by academic self-concept. Research Journal in Organizational Psychology \& Educational Studies 3(3) 184-188. Retrieved from http://rjopes.emergingresource.org/articles/ NONACADEMIC SELF CONCEPT.pdf

[4] Good, C.V. (19793). Dictionary of education (3 ${ }^{\text {rd }}$ Edition) New York: Mc Graw Hill Book Company.

[5] Johnson and Medinus (1969). Quoted in the manual of home environment inventory, by K.S Mishra, Ankur Psychological Agency, Lucknow.

[6] Menzel, W. E. (1982). How to Study Effectively. London Oxford University Press

[7] Onoshakpokaiyee, O.(2015).Relationship of Study Habits with Mathematics Achievement. Journal of Education and Practice, 6(10), 168-169. Retrieved from

[8] http://iiste.org/Journals/index.php/JEP/article/downloa $d / 21452 / 22160$

[9] Singh, R., \& Sarka, S. (2015) Learning Environments in Andhra Pradesh, India: Children's Academic SelfConcepte $^{\text {ee }}$ and Mathematics Achievement. Oxford Department of International Development (ODID), University of Oxford, Queen Elizabeth House, 3 Mansfield Road, Oxford OX1 3TB, UK. Retrived from http://www.younglives.org.uk/publications/WP/learning -environments-inandhrapradesh/YLWP137_Learning\%20environments \%20in\%20Andhra\%20Pradesh.pdf

[10] Viji, V. (2013).A study on study habits, attitude towards mathematics and achievement in mathematics of secondary school students in Kanchipuram District, SRM University, Kattaukulathur. 